Article

\title{
Determinants of Catch Sales in Ghanaian Artisanal Fisheries
}

\author{
Kwamena K. Quagrainie ${ }^{1, *(1)}$ and Jingjie Chu ${ }^{2}$ \\ 1 Department of Agricultural Economics, Purdue University, 403 W. State St., West Lafayette, IN 47907, USA \\ 2 Environment and Natural Resources Global Practice, The World Bank, 8602 SW 42nd Pl, \\ Gainesville, FL 32608, USA; jingjie.chu@gmail.com \\ * Correspondence: kquagrai@purdue.edu
}

Received: 20 November 2018; Accepted: 4 January 2019; Published: 9 January 2019

check for updates

\begin{abstract}
The study examined the determinants of catch sales of artisanal fishers through wealthy middle women in fishing communities of Ghana, often known as fish mothers or "fish mongers". The effects of selected variables were examined with a double hurdle model. Self-financing was found to negatively affect the fishers' sale of fish catch through fish mothers. The fishers were $19 \%$ less likely to sell to fish mothers if they self-finance, and that self-financing will result in a $10 \%$ downward unconditional change on the percentage of fish sold to the fish mothers. Factors that positively influenced the sale of fish catch through the fish mothers were price, percentage of high value fishes, size of boat, fishing experience, and number of fishing trips conducted in a year. The estimated average partial effects of boat size had the strongest effect with about $146 \%$ and $91 \%$ change, respectively on conditional and unconditional effect on the percentage of catch sales sold through the fish mothers. Overall, the study shows that long-term consistent economic and investment considerations such as investing in larger boats are important drivers for fishers' choice of selling catches through fish mothers. The main implication of the results is that fishers need some economic leverage such as access to formal capital and financial resources to incentivize them to exercise control over their marketing activities so that they can receive a higher profit from their fishing operations. This is important for the sustainability of coastal fisheries communities and the sector as a whole. Artisanal fishers need resources such as low interest loans and market information systems that will enable them to negotiate prices for their fish catch with fish mothers.
\end{abstract}

Keywords: artisanal fishers; double-hurdle; fish marketing; fish mothers

\section{Introduction}

Ghana is an advanced fishing country relative to other African countries with very experienced fishers, which has been attributed to long traditions from the colonial era. Marine fishing in Ghana was developed mainly with the arrival of European traders when the Europeans hired fishers as canoe men to transport people and goods from their ships to the beaches, and vice-versa [1]. The marine capture fishery in Ghana is the major source of local fish production, accounting for over $80 \%$ of the total fish product supply [2]. The sector consists of four subsectors: small scale or artisanal, semi-industrial or inshore, industrial or deep sea, and tuna fleets. The fishing sector plays a major role in poverty reduction and livelihoods for coastal communities, which is estimated to contribute about 1.2 percent of Ghana's gross domestic product (GDP) and 5.6 percent of the Agriculture GDP [2,3]. The low national GDP contribution from the fisheries sector is due to declining fisheries stocks [3]. The small scale or artisanal subsector accounts for about half of the total marine catch in Ghana [2,4], which makes it important for the sustainability of the fisheries sector. 
The artisanal fishery involves the use of canoes or dug-out wooden boats with inboard or outboard engines. The fishing gears are diverse, including beach seine nets, purse seine nets, set nets, drift gillnets, and hook and line. The major commercial species landed are small pelagic low value fishes such as anchovies (Engraulis spp.), sardinellas (Sardinella spp.), and mackerels (Scomber spp.). Large motorized canoes or boats operate in deep waters and have storage facilities or compartments on board for storing ice to preserve catches. The main fishes landed by artisanal fishers include sardinellas (mainly Sardinella aurita), tuna (Auxis thazard), mackerels (mainly Scomber japonicas), burrito (Brachydeuterus auritus), and Atlantic bumper (Chloroscombrus chrysurus). Some of the minor fishes landed include red fish (mainly Sparus caeruleostictus and Dentex angolensis), anchovies (Engraulis encrasicolus), flat fish species, and the white grouper (Epinephelus aeneus), some of which are considered high value fishes. Most of the fishers target high value species such as white grouper, tuna, and red fish because of the high demand and premium prices, however the percentage of these fishes landed are low due to the fishing methods used and unhealthy fish stocks $[5,6]$.

The artisanal fishery plays an important role in coastal communities by providing employment, income, and a cheap source of protein. The major challenges they face are seasonality, small margins and low returns $[5,7,8]$. The sector's performance is critical for the growth, economic development, and sustainability of the coastal communities. The returns accruing to artisanal fisheries are affected by several factors including limited value addition and consequent post-harvest losses, weak backward-forward market linkages, poor infrastructure, low bargaining power, as well as low and lack of variety of catch. Expenses associated with fishing activities include fuel, food, labor, taxes, and other variable overheads.

Women are important players in the small-scale fisheries subsector in developing countries. Their participation rate in pre- and post-harvesting activities is estimated at about $48 \%$, and in Ghana, it is around $40 \%$ [9]. Women participation in the subsector is higher if only post-harvest is considered. In particular, women in Ghana have a vital role in informal financing of fishing operations [7,10], partly due to lack of access to financial support from other channels like bank loans.

The marketing system and remuneration for the artisanal fishery take a number of forms. A proportion of the catch goes to wealthy middle-women, often known as "fish mothers" or "fish mongers" to cover any pre-financing arrangements; a portion is sold or given to the boat owner to cover fixed costs (boat and fishing gear); hired laborers may receive a portion of the catch as wages; and smaller portions are shared [10]. Thus, fish may be sold through fish mothers as well as other female fish value chain agents including fish processors, fish retailers, food vendors, relatives, and spouses. Some spouses may also be fish mothers. Fishing is a capital-intensive industry, and an advantage to fishers for selling their catch to fish mothers is the reciprocal leverage they have to secure relatively low cost capital to finance their business like fuel cost. Selling fish catch to fish mothers has less risk as it is a cash market, and usually fish mothers can buy high volumes of fish landed. Fishers can obtain higher prices especially from fish mothers who primarily serve distant regional, or national, and in some cases international markets [7]. However, there are some disadvantages for selling to fish mothers. Fish mothers have often used their financing leverage to acquire and own fishing equipment used by the fishers and therefore control the production chain [10].

The traditional roles for women in the fishing industry in Ghana, which were structured through responsibilities and customary roles for accessing resources are gradually changing [10]. Traditionally, a fisher is required to provide fresh fish from his catch to his spouse for retailing either as fresh or processed products to generate income to maintain the household as well as to provide income for further investments in the fishing business. However, there are increasing capital costs associated with artisanal fisheries due to the use of larger canoes, high powered motors, and expensive fishing equipment, and limited access to formal bank credit because of a low loan repayment rate arising from poor loan management, low catches, high risks of industry participation, and relatively high indebtedness of fishers [11]. Therefore, it appears fishers are increasingly taking control of their 
earnings to ensure capital is available to invest in the fishing business, thus taking away the traditional fish marketing role from their spouses [7,10].

Artisanal fishers carry out their transactions through various marketing channels including middle-women, spouses, processors, small traders, food vendors, and direct to end users. Each channel provides some level of benefits and returns. Fish mothers tend to pre-finance fishing trips of fishers who need credit with fuel and food in exchange for secure access to the catch from the fishers. In the artisanal fishery value chain in Ghana, it is commonly perceived that fish mothers and processors accrue a greater percentage of the profit margins generated along the fisheries value chain, followed by retail traders, and then the fishers. The literature on food and product markets in developing countries has overwhelmingly reported increasing power of middlemen, intermediaries and retailers, and their tendency to negotiate lower prices from producers [12-14]. Fish mothers usually trade diverse food products, which gives them more access to capital, providing them some leverage with both fishers, processors and retail traders [10]. Fish mothers can pre-finance several fishers and consequently have access to ample supply of fish. Such arrangements tend to place some power in the hands of the fish mothers at various landing sites $[7,10]$.

The motivation for and determinants of fishers' choices and decisions regarding who to sell fish have not been empirically tested, though commonly, fish mothers are the preferred choice for selling fish catch. This study seeks to fill that information gap by examining the relationship between the fishers' decisions to sell fish catch and the percentage of catch sold through fish mothers and a number of economic and socio-demographic factors. Since fish mothers commonly pre-finance fishing trips of some fishers in the form of fuel and food, which in turn force the fishers to sell through fish mothers, the main hypothesis examined in this study is whether fishers' self-financing affects the decision to sell through fish mothers and the actual percentage of catch sales through them. Other factors examined include input characteristics such as boat size, number of fishing trips per year, as well as some demographic characteristics.

\section{Modeling Framework and Empirical Specifications}

The Double Hurdle (DH) model [15-17] is adopted to examine the fisher's marketing decision to sell fish catch through fish mothers. The decision process is assumed to involve two hurdles: the first hurdle relates to whether or not the fisher will sell their catch to fish mothers $\left(y_{1 i}^{*}\right)$, and the second relates to the percentage of fish catch sold through fish mothers $\left(y_{2 i}^{*}\right)$. The hurdles involve zeros because some fishers do not sell fish catch through fish mothers at all. The DH model addresses the zero outcomes arising from the fishers' deliberate decisions, and it is a more general and flexible model than other models such as the Tobit model [18] by allowing separate stochastic processes for the incidence and intensity of sales [19]. The DH model is commonly applied to market participation studies [17,20-25].

The DH model allows the decision to sell to fish mothers and the percentage of sales to be determined by two different stochastic processes. Thus, the model permits the possibility of estimating the first and the second decision processes using a different set of explanatory variables.

In the first hurdle, the latent variable underlying the fisher's decision to sell to fish mothers is represented as a binary process:

$$
y_{1 i}^{*}=\gamma_{1}^{\prime} X_{1 i}+\pi_{i} \quad \pi_{i} \sim N(0,1)
$$

where $X_{1 i}$ is a vector of explanatory variables, and $\pi_{i}$ is the error term. The observed decision of the fisher is then modeled as:

$$
y_{1 i}= \begin{cases}1 & \text { if } y_{1 i}^{*}>0 \\ 0 & \text { otherwise }\end{cases}
$$

In the second hurdle, the latent variable describing the percentage of fish catch sold to fish mothers is represented as:

$$
y_{2 i}^{*}=\gamma_{2}^{\prime} X_{2 i}+\vartheta_{i} \quad \vartheta_{i} \sim N\left(0, \sigma^{2}\right)
$$


where $\vartheta_{i}$ is the error term, and the observed percentages is represented as:

$$
y_{i}=\left\{\begin{array}{cl}
\gamma_{2}^{\prime} X_{2 i}+\vartheta_{i} & \text { if } y_{1 i}^{*}>0 \text { and } y_{2 i}^{*}>0 \\
0 & \text { otherwise }
\end{array}\right.
$$

and the $\Upsilon_{S}$ are coefficients to be estimated.

Given the cross-sectional nature of the data, the DH model is estimated using maximum likelihood estimation procedures and tested for potential presence of heteroscedasticity using a chi-squared test. If there is heteroscedasticity, the model estimates will be inconsistent. Consequently, the variance of the error term in Equation (4), $\sigma^{2}$ is allowed to vary across observations. The standard deviation $\sigma_{i}$ is specified as:

$$
\sigma_{i}=\sigma \cdot \exp \left(\delta^{\prime} \mathbf{h}_{2 i}\right)
$$

where $\mathbf{h}_{2 i}$ is a vector of select continuous variables included in $X_{2 i}$, and $\delta$ is a vector of coefficients [22]. If the model is homoscedastic, $\delta=0$. The specification in Equation (5) ensures that the standard deviation is strictly positive [24,25].

The DH models outlined above with and without specification adjustments for heteroscedasticity were estimated for fishers' decisions to sell fish catch through fish mothers using the LIMDEP software version 10.0.

The data used in the study was collected in the summer of 2013 from artisanal fishers at major coastal fishing communities in Ghana, i.e., Chorkor, Jamestown, and Tema in the Greater Accra region, and Elmina, Cape Coast, and Moree in the Central region. The semi-structured questionnaire solicited information on the major activities and services of fishers, costs and revenues associated with their activities, fish landed, prices, business transaction methods, marketing channels, fishing gear used, and demographic factors. The subjects were selected randomly and surveyed at each fishing community.

\section{Data}

Data was collected from 202 artisanal fishers but only 96 responses were used in this analysis because they corresponded to the full responses provided for the relevant variables needed for the analysis. Information on the method of transaction was also collected, and whether they self-financed fishing operations. Information on the percentage of fish sold through fish mothers or other marketing outlets was also collected. Other outlets consist of mainly spouse and relatives, and direct to consumers. Fish mothers generally operate as wholesalers [10]. Other information includes the size of fishing boat.

The variables used in the estimation process are reported in Table 1. The proportion of artisanal fishers selling to fish mothers is about $77 \%$, and on average, about $73 \%$ of their fish catch was sold through fish mothers. Fish prices generally varied with season and fish species. There are two major fishing seasons in Ghana: the major upwelling or bumper season, which is usually from the end of June or early July through late September or early October, and the minor upwelling season, which occurs from late December or early January through February [26]. Respondents reported the composition of fish landed in the past three fishing seasons. They also reported the prices received for the various species in both the major and minor seasons. The price of the fish landed depended on demand and supply, costs, and grade. A weighted average price was therefore calculated for the analysis based on the season and value of fish. Table 1 shows that prices on average ranging from $\$ 1.50 / \mathrm{kg}$ to $\$ 22.5 / \mathrm{kg}$. 
Table 1. Description and Summary Statistics of Variables.

\begin{tabular}{lccc}
\hline \multirow{2}{*}{ Variable } & \multicolumn{3}{c}{ Sample Statistics (n = 96) } \\
\cline { 2 - 4 } & Mean & Min & Max \\
\hline Dep. Var. Hurdle 1: Sold to fish mothers (=1) & 0.77 & 0 & 1 \\
Dep. Var. Hurdle 2: Percentage fish catch sold & 72.83 & 0 & 100 \\
through fish mothers (\%) & & & \\
Explanatory Variables: & 4.10 & 1.5 & 22.6 \\
Weighted average price of all fishes (US\$/kg) & 25.00 & 0 & 100 \\
Percentage of high value fish landed (\%) & 0.55 & 0 & 1 \\
Self-financing for fishing activities (=1) & 16.41 & 8.0 & 27.0 \\
Boat size (meters) & 19 & 3 & 41 \\
Experience (number of years fishing) & 243 & 12 & 317 \\
Number of fishing trips in a year & 0.87 & 0 & 1 \\
At least a primary education (=1) & 0.78 & 0 & 1 \\
Located in Greater Accra (=1) & & & \\
\hline
\end{tabular}

Based on multiple responses, $30.6 \%$ of fishers reported landing Sardinella spp., $16.1 \%$ tuna, $15.4 \%$ mackerels, $13.5 \%$ burrito, $12.3 \%$ Atlantic bumper, $5.6 \%$ red fish, $2.7 \%$ anchovies, $2.5 \%$ Soleidae spp., and $1.2 \%$ white grouper. The FAO [2] also reported that sardines and mackerel are among the commonly landed fish species in Ghana, and constitute the most commercially important coastal fisheries. The fishers reported low landing of shrimps (mainly Parapenaeopsis atlantica and Penaeus kerathurusthat), Atlantic bigeye (Priacanthus arenathus), European barracuda (Sphyraena sphyraena), Trigger fish (Balistes punctatus / capriscus), and Bigeye Scad (Selar crumenophthalmus). White grouper, tuna, and red fish are considered high value fish.

Most of the fishers have at least a primary education (87\%), and the average fishing experience was 19 years. Over half (55\%) of the fishers were self-financing their fishing operations. Fishers used a range of canoe (boat) sizes varying from $8 \mathrm{~m}$ to $27 \mathrm{~m}$, with an average of $16.4 \mathrm{~m}$. The average number of trips per year ranged from 12 to as many as 317 .

\section{Results and Discussion}

A chi-square test statistically rejected the homoscedastic model in favor of the heteroscedastic model with an alternative variance specification (Table 2). Tables 3 and 4 present the maximum likelihood estimates for the homoscedastic and heteroscedastic models respectively. To assess the total impact of the explanatory variables on fishers' decisions, the Average Partial Effects (APEs) from the heteroscedastic model are discussed (Table 5). The APEs are evaluated at the means of each variable. They are decomposed into three components, i.e., the effect on the probability of selling fish catch to fish mothers (Prob $[y>0]$ ), the effect on the unconditional expected value of percentage fish sold to the fish mothers $(E[y])$, and the effect on expected value of percentage fish sold to the fish mothers conditional on positive expected value (E[y|y>0]).

Table 2. Likelihood ratio tests of homoscedasticity restriction.

\begin{tabular}{ll}
\hline & Estimate \\
\hline Homoscedastic Model & LLF $=-52.521$ \\
Heteroscedastic Model & $\mathrm{LLF}=-33.808$ \\
$\chi^{2}$ test statistic & 37.426 \\
$\chi^{2}(1,0.01)$ critical value & 6.63 \\
\hline
\end{tabular}


Table 3. Estimated parameters from homoscedastic double-hurdle model ${ }^{\mathrm{a}}$.

\begin{tabular}{|c|c|c|}
\hline \multirow[t]{2}{*}{ Variable } & $\begin{array}{c}\text { Hurdle 1: } \\
\text { If Sold to } \\
\text { Fish Mothers }\end{array}$ & $\begin{array}{c}\text { Hurdle 2: } \\
\text { \% Sold through } \\
\text { Fish Mothers }\end{array}$ \\
\hline & Coefficient $\left(\gamma_{1}\right)$ & Coefficient $\left(\gamma_{2}\right)$ \\
\hline Weighted average price of all fishes (US\$) & & $\begin{array}{c}0.021 \text { ** } \\
(0.014)\end{array}$ \\
\hline Percentage of high value fish landed (\%) & & $\begin{array}{c}0.004^{* * *} \\
(0.001)\end{array}$ \\
\hline Self-financing for fishing activities $(=1)$ & $\begin{array}{c}-0.652 \text { ** } \\
(0.036)\end{array}$ & $\begin{array}{l}-0.058 \\
(0.445)\end{array}$ \\
\hline Boat size (meters) & $\begin{array}{l}0.367^{* *} \\
(0.027)\end{array}$ & $\begin{array}{c}0.871^{* * *} \\
(0.000)\end{array}$ \\
\hline Experience (years) & & $\begin{array}{c}0.197^{* * *} \\
(0.000)\end{array}$ \\
\hline Number of fishing trips in a year & & $\begin{array}{c}0.229 \\
(0.195)\end{array}$ \\
\hline At least a primary education $(=1)$ & $\begin{array}{c}0.142 \\
(0.773)\end{array}$ & $\begin{array}{c}0.164 \\
(0.168)\end{array}$ \\
\hline Located in Greater Accra $(=1)$ & & $\begin{array}{c}0.035 \\
(0.708)\end{array}$ \\
\hline
\end{tabular}

${ }^{\text {a }} p$-values are given in parentheses; ${ }^{* * *}$ and ${ }^{* *}$ represent significance at $\alpha=0.01$ and $\alpha=0.05$ respectively.

Table 4. Estimated parameters from heteroscedastic double-hurdle model ${ }^{\text {a }}$.

\begin{tabular}{|c|c|c|c|}
\hline \multirow[t]{2}{*}{ Variable } & $\begin{array}{c}\text { Hurdle 1: } \\
\text { If Sold to Fish Mothers }\end{array}$ & $\begin{array}{c}\text { Hurdle 2: } \\
\text { \% Sold to Fish Mothers }\end{array}$ & $\begin{array}{c}\text { Heterogeneous } \\
\text { Equation }\end{array}$ \\
\hline & Coeff. $\left(\gamma_{1}\right)$ & Coeff. $\left(\gamma_{2}\right)$ & Coeff. ( $(\delta)$ \\
\hline Weighted average price of all fishes (US\$) & & $\begin{array}{c}0.015^{* * *} \\
(0.001)\end{array}$ & \\
\hline Percentage of high value fish landed (\%) & & $\begin{array}{l}0.002^{*} \\
(0.051)\end{array}$ & \\
\hline Self-financing for fishing activities $(=1)$ & $\begin{array}{l}-0.676^{* *} \\
(0.033)\end{array}$ & $\begin{array}{c}0.050 \\
(0.333)\end{array}$ & \\
\hline Boat size (meters) & $\begin{array}{l}0.320^{* * *} \\
(0.009)\end{array}$ & $\begin{array}{l}1.211^{* * * *} \\
(0.000)\end{array}$ & $\begin{array}{l}-2.913^{* * *} \\
(0.001)\end{array}$ \\
\hline Experience (years) & & $\begin{array}{l}0.105^{* * *} \\
(0.002)\end{array}$ & \\
\hline Number of fishing trips in a year & & $\begin{array}{l}0.107^{* * *} \\
(0.000)\end{array}$ & \\
\hline At least a primary education $(=1)$ & & $\begin{array}{c}0.022 \\
(0.780)\end{array}$ & \\
\hline Located in Greater Accra (=1) & $\begin{array}{c}0.351 \\
(0.337)\end{array}$ & $\begin{array}{c}0.012 \\
(0.836)\end{array}$ & \\
\hline
\end{tabular}

${ }^{a} p$-values are given in parentheses; ${ }^{* * *}, * *$ and ${ }^{*}$ represent significance at $\alpha=0.01, \alpha=0.05$, and $\alpha=0.10$ respectively.

Table 5. Estimated average partial effects (APE) from heteroscedastic double-hurdle model.

\begin{tabular}{|c|c|c|c|}
\hline \multirow{2}{*}{ Variable } & $\operatorname{Prob}[y>0]$ & $\mathrm{E}[\mathrm{y}]$ & $E[y \mid y>0]$ \\
\hline & Coeff. & Coeff. & Coeff. \\
\hline Weighted average price of all fishes (US\$) & $0.004^{* * * b}$ & $0.001 * * *$ & $0.001 * * *$ \\
\hline Percentage of high value fish landed (\%) & 0.000 & 0.000 & 0.000 \\
\hline Self-financing for fishing activities $(=1)$ & $-0.190^{* *}$ & $-0.102 * *$ & $0.012 * *$ \\
\hline Boat size (meters) & $0.094^{* * *}$ & $1.461^{* * *}$ & $0.913^{* * *}$ \\
\hline Experience (years) & $0.025^{* * * b}$ & $0.008^{* * *}$ & $0.005^{* * *}$ \\
\hline Number of fishing trips in a year & $0.026^{* * * b}$ & $0.008^{* * *}$ & $0.005^{* * *}$ \\
\hline At least a primary education $(=1)$ & $0.005^{\mathrm{b}}$ & 0.002 & 0.001 \\
\hline Located in Greater Accra $(=1)$ & 0.100 & 0.056 & 0.005 \\
\hline
\end{tabular}


The choice of explanatory variables included in the two hurdles is based on some economic theory and reasoning. Fishers are considered as rational businessmen and to take decisions to maximize their economic returns. In the literature, the first hurdle, which is based on the discrete choice preference theory, is often specified as a function of non-economic factors because the theory assumes that sample selection is determined by non-economic factors such as demographic characteristics [22,23]. In Table 4, price, percentage of high value fish landed, and some characteristics such as boat size, number of fishing trips per year as well as experience (measured as number of years of fishing) have a positive and significant effect. The APEs reported in Table 5 are positive and significant as well, which indicates the positive responsiveness of fish sold to fish mothers to changes in these factors. Self-financing of fishing trips is found to negatively impact fish sold to fish mothers.

Self-financing fishing trips relative to other forms of financing fishing activities negatively impacts the decision to sell to fish mothers (Table 4). The magnitude of the estimated APEs (Table 5) suggests that it is important and that fishers are $19.0 \%$ less likely to sell to fish mothers if they self-finance their fishing operations. Also, self-financing will result in a 10.2\% downward change on the unconditional percentage of fish sold to the fish mothers. As indicated earlier, some fish mothers pre-finance fishing trips of fishers to secure access to their catch. Consequently, self-financed fishers are not obligated to sell their fish through the fish mothers. Such fishers may be mindful of their economic portfolio and the flow back of resources to the household. They could probably sell through their spouses or relatives $[10,27]$. However, conditional on a positive decision to sell fish to the fish mothers, self-financing will result in just a $1.2 \%$ upward change in the percentage of fish catch sold.

From Tables 4 and 5, the positive effect of price, though relatively small is perhaps due to the ability of fishers to negotiate prices with the fish mothers. The change in price on both conditional and unconditional sale of fish catch to fish mothers is about $0.1 \%$ ceteris paribus, i.e., all else unchanged (Table 5). Traditionally, fish landed are priced by the Fish Queen, the Head of fish mothers in consultation with the Chief fisher $[7,10,27]$. However, some fishing communities have invested in improved landing facilities, and charge landing fees, which then allows the fishers to negotiate prices on individual basis with the fish mothers [7]. In addition, fish mothers buying fish to sell in markets with better prices may offer fishers more competitive prices. A similar interpretation could apply to the positive impact of high value fishes. Low value fish such as Sardinellas are often in commercial abundance, which impacts its value. To prevent waste, Sardinellas tend to be preserved through smoking or drying. However, the percentage catches of high value fishes such as red fish (Dentex spp.) are relatively low (25\% in Table 1) and they are sold fresh. Fish mothers would likely offer higher prices due to the high demand and high profit.

The size of boat is found to be a significant variable and positively impact the probability of selling to fish mothers and the percentage of fish sold to them (Table 4). The magnitude of the estimated coefficient (0.32 in Hurdle 1 and 1.21 in Hurdle 2-Table 4) is the strongest compared to the other variables. The change in boat size on both conditional and unconditional sale of fish catch to fish mothers is about $146 \%$ and $91 \%$, respectively (Table 5 ) suggesting a very strong effect. Larger boats operate in a wider area, from near landing sites to relatively more open waters, and as such exploit more catches compared to smaller boats [28]. Larger boats can also handle and store fish in good condition on board as they are motorized, and most are equipped with hydraulic hauling machinery, fish-finding electronics, ice, and storage facilities, which improves the efficiency of fishing and handling of fish [29]. Perhaps, the strong impact of having larger boats on fish sold through fish mothers results from higher fish catches and requires a higher purchasing power to absorb all the fish caught.

Regarding fishers' experience, a one-year change in fishing experience on both conditional and unconditional probability of sale of fish catch to fish mothers is about $0.8 \%$ and $0.5 \%$, respectively (Table 5). Similar probabilities are found for the number of fishing trips taken in a year (Table 5). Though the experience variable has a relatively small effect, it is likely that experienced fishers have better understanding of fish movements, and consequently better fish catch. Also, experienced fishers may have a better knowledge of the fish markets and social connections that could make them to sell 
to fish mothers. Knowledge gained from fishing experience is reported to influence relocation of fishers along the west coast of Africa [30] and loan repayments by fishers [11]. Regarding the number of trips, the probabilities imply that the higher the number of trips, the higher the effect on fish sold to the fish mothers as a more consistent relationship was set up.

\section{Conclusions}

This study assessed the determinants of marketing decisions of artisanal fishers regarding the fish catch sold through fish mothers. The empirical model was a double-hurdle that addressed the zero outcomes arising from the fishers' deliberate decisions not to sell through fish mothers.

Self-financing of fishing trips was found to negatively impact fish sold to fish mothers. It is the only variable that has a negative impact. The magnitude of the estimated coefficients suggests that self-financing has a strong effect, i.e., fishers were $19 \%$ less likely to sell to fish mothers if they self-finance their fishing activities as they will receive higher prices without the binding agreements with the fish mothers, and that self-financing will result in a $10 \%$ downward change on the unconditional percentage fish sold to the fish mothers. Such fishers would probably sell through their spouses or family relatives.

The impact of price, percentage of high value fish landed, boat size, number of fishing trips per year as well as fishing experience were found to have a positive and significant effect on the percentage of fish sold through fish mothers. The estimated average partial effects suggest that boat size had the strongest effect on fish sold through the fish mothers, with about $146 \%$ and $91 \%$ change, respectively on conditional and unconditional sale of fish catch, which is likely caused by higher catches. But price, percentage of high value fish landed, the number of fishing trips per year and fishing experience had relatively smaller effects.

Overall, the study shows that long-term consistent economic and investment considerations such as investing in larger boats are important drivers for fishers' choice of selling catches through fish mothers. Larger boats operate in wider and deep waters and have higher hauling capacity and as such exploit more catches. The main implication of the results is that fishers need some economic leverage such as access to formal capital and financial resources to incentivize them to exercise control over their marketing activities so that they can receive a higher profit from their fishing operations. This is important for the sustainability of coastal fisheries communities and the sector as a whole. Artisanal fishers need resources such as low interest loans and market information systems that will enable them to negotiate prices for their fish catch with fish mothers.

Author Contributions: Formal analysis, K.K.Q.; Writing—review \& editing, J.C.

Funding: The research was funded by the World Bank Group, grant number 7832381.

Acknowledgments: The research was funded by the World Bank Group.

Conflicts of Interest: The authors have no conflict of interest.

\section{References}

1. Law, R. Between the Sea and the Lagoons: The Interaction of Maritime and Inland Navigation on the Precolonial Slave Coast. Cah. d'Études Afr. 1989, 114, 209-237. [CrossRef]

2. Food and Agriculture Organization of the United Nations-FAO. Fishery and Aquaculture Country Profiles. The Republic of Ghana; FID/CP/GHA, FAO: Rome, Italy, February 2016; Available online: http: / www.fao.or $\mathrm{g}$ / fishery / facp/GHA/en\#pageSection2 (accessed on 7 December 2017).

3. Ghana Statistical Service. Statistics for Development: Provisional 2017 Annual Gross Domestic Product; Ghana Statistics Service Publication: Accra, Ghana, April 2018. Available online: http:/ / www.statsghana.gov.gh/docfiles/GDP/GDP2018/2017\%20Quarter\%204\%20and\%20annual\%20201 7\%20GDP\%20publications /Annual_2017_GDP_April\%202018\%20Edition.pdf (accessed on 11 December 2018).

4. Amador, K.; Bannerman, P.; Quartey, R.; Ashong, R. Ghana Canoe Frame Survey. Information; Report Number 34; Marine Fisheries Research Division, Ministry of Fisheries: Tema, Ghana, 2006; 43p. 
5. Aheto, D.W.; Asare, N.K.; Quaynor, B.; Tenkorang, E.Y.; Asare, C.; Okyere, I. Profitability of Small-Scale Fisheries in Elmina, Ghana. Sustainability 2012, 4, 2785-2794. [CrossRef]

6. Antwi-Asare, T.O.; Abbey, E.N. Fishery Value Chain Analysis-Ghana. FAO Report. 2011. Available online: www.fao.org/fileadmin/user_upload/fisheries/docs/Ghana_edited.doc (accessed on 7 October 2016).

7. Gordon, A.; Pulis, A.; Owusu-Adjei, E. Smoked Marine Fish from Western Region, Ghana: A Value Chain Assessment; WorldFish Center, USAID Integrated Coastal and Fisheries Governance Initiative for the Western Region, Ghana: Cape Coast, Ghana, 2011; 46p, Available online: http:/ /www.worldfishcenter.org/resource _centre/WF_2916.pdf (accessed on 3 November 2017).

8. Mensah, J.V.; Antwi, B.K. Problems of Artisanal Marine Fishermen in Ghana: The Way Ahead. Singap. J. Trop. Geogr. 2002, 23, 217-235. [CrossRef]

9. FAO; WorldFish Center; World Bank. Small-scale Capture Fisheries-A Global Overview with Emphasis on Developing Countries: A Preliminary Report of the Big Numbers Project; FAO: Rome, Italy; WorldFish Center: Penang, Malaysia, 2008; 62p.

10. Britwum, A.O. The Gendered Dynamics of Production Relations in Ghanaian Coastal Fishing. Fem. Afr. 2009, 12, 69-85.

11. Acquah, H.D.; Addo, J. Determinants of Loan Repayment Performance of Fishermen: Empirical Evidence from Ghana. Cercetări Agron. Mold. 2011, 148, 89-97.

12. Pokhrel, D.M.; Thapa, G.B. Are Marketing Intermediaries Exploiting Mountain Farmers in Nepal? A Study Based on Market Price, Marketing Margin and Income Distribution Analyses. Agric. Syst. 2007, 94, 151-164. [CrossRef]

13. Chau, N.H.; Goto, H.; Kanbur, R. Middlemen, Non-Profits, and Poverty. (No. 4406). IZA Discussion Papers. 2009. Available online: https:/ / www.econstor.eu/dspace/bitstream/10419/36013/1/612901726.pdf (accessed on 3 November 2017).

14. Brooks, S.E.; Kebede, B.E.; Allison, H.; Reynolds, J.D. The Balance of Power in Rural Marketing Networks: A Case Study of Snake Trading in Cambodia. J. Dev. Stud. 2010, 46, 1003-1025. [CrossRef]

15. Cragg, J.G. Some Statistical Models for Limited Dependent Variables with Application to the Demand for Durable Goods. Econometrica 1971, 39, 829-844. [CrossRef]

16. Blundell, R.W.; Meghir, C. Bivariate alternatives to the univariate Tobit model. J. Econom. 1987, 33, $179-200$. [CrossRef]

17. Jones, A.M. A double-hurdle model of cigarette consumption. J. Appl. Econom. 1989, 4, 23-39. [CrossRef]

18. Tobin, J. Estimation of Relationships for Limited Dependent Variables. Econometrica 1958, 26, $24-36$. [CrossRef]

19. Jones, A.M. Double Hurdle Model. Wiley StasRef: Statistics Reference Online. 2018. Available online: https: / / doi.org/10.1002/9781118445112.stat08074 (accessed on 19 December 2018).

20. Mather, D.; Boughton, D.; Jayne, T.S. Explaining smallholder maize marketing in southern and eastern Africa: The roles of market access, technology and household resource endowments. Food Policy 2013, 43, 248-266. [CrossRef]

21. Komarek, A. The determinants of banana market commercialisation in Western Uganda. Afr. J. Agric. Res. 2010, 5, 775-784.

22. Aristei, D.; Pieroni, L. A Double-Hurdle Approach to Modelling Tobacco Consumption in Italy. Appl. Econ. 2008, 40, 2463-2476. [CrossRef]

23. Yen, S.T. A Multivariate Sample-selection Model: Estimating Cigarette and Alcohol Demands with Zero Observations. Am. J. Agric. Econ. 2005, 87, 453-466. [CrossRef]

24. Ricker-Gilbert, J.J.; Thomas, S.; Chirwa, E. Subsidies and crowding out: A double-Hurdle model of fertilizer demand in Malawi. Am. J. Agric. Econ. 2011, 93, 26-42. [CrossRef]

25. Rude, J.; Surry, J.; Kron, R. A generalized double-hurdle model of Swedish gambling expenditures. Appl. Econ. 2014, 46, 4151-4163. [CrossRef]

26. Cobblah, M.A.; Jiagge, M. Repackaging Marine and Aquatic Information for Fishermen in Ghana: The Way Forward. Council for Scientific and Industrial Research Report. 2003. Available online: https:/ / darchive.m blwhoilibrary.org/bitstream/handle/1912/699/proc02169.pdf?sequence=1 (accessed on 15 August 2017).

27. Ward, A.R.; Bortey, A.; Whittingam, E.; Braimah, L.I.; Ashong, K.; Wadzah, N. Poverty and Post-Harvest Fishery Livelihoods in Ghana; Output from the Post-Harvest Fisheries Research Programme Project R8111; IMM Ltd.: Exeter, UK, 2004. 
28. Food and Agriculture Organization of the United Nations-FAO. Fisheries and Aquaculture Topics—Small-Scale and Artisanal Fisheries; Johnson, J., Ed.; FAO Fisheries and Aquaculture Department: Rome, Italy, 2005; Available online: http:/ / www.fao.org/fishery/topic/14753/en (accessed on 15 August 2017).

29. Food and Agriculture Organization of the United Nations-FAO. Fisheries and Aquaculture Topics-Fishing Vessels; Turner, J., Ed.; FAO Fisheries and Aquaculture Department: Rome, Italy, 2005; Available online: http:/ / www.fao.org/fishery/topic/1616/en (accessed on 15 August 2017).

30. Marquette, C.M.; Koranteng, K.A.; Overå, R.; Aryeetey, E.B.D. Small-Scale Fisheries, Population Dynamics, and Resource Use in Africa: The Case of Moree, Ghana. Ambio 2002, 31, 324-336. [CrossRef] [PubMed]

(C) 2019 by the authors. Licensee MDPI, Basel, Switzerland. This article is an open access article distributed under the terms and conditions of the Creative Commons Attribution (CC BY) license (http://creativecommons.org/licenses/by/4.0/). 